Biol. Stud. 2015: 9(2); 207-210 • DOI: https://doi.org/10.30970/sbi.0902.440

www.http://publications.Inu.edu.ua/journals/index.php/biology

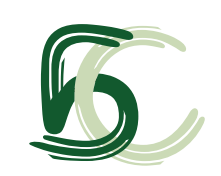

UDC 502.1:504.61(477.8)

\title{
FRAGMENTATION DEGREE AND EFFECTIVE MESH SIZE OF NATURE-PROTECTED AREAS OF THE WESTERN UKRAINE
}

\section{O. Reshetylo}

Ivan Franko National University of Lviv, 4, Hrushevskyi St., Lviv 79005, Ukraine e-mail: reshetylo@yahoo.com

Anthropogenic fragmentation of natural landscape takes on a global character. An increasing degree of the anthropogenic fragmentation undermines stability and reduces productivity of ecosystems all over the world. Index of landscape fragmentation $\left(m_{\text {eff }}\right)$ was used for realization of idea on evaluation of the degree of landscape fragmentation and its effective mesh size on the example of 17 nature-protected areas in the Western Ukraine. Railways, hard surface roads and completely built-up areas were the factors considered to cause landscape fragmentation. On the basis of our survey, we found out that total size of a protected area is not the main criterion of its effectiveness for biodiversity conservation, and high degree of landscape fragmentation has a significant negative impact on index of landscape fragmentation. Besides, not only the degree but also the pattern of fragmentation has a significant influence on the effective mesh size. Taking into account the negative effects of landscape fragmentation as one of the threats for biodiversity on the territory of protected sites, we consider a possibility of combining the adjacent areas of Roztochchia NR and Yavorivskyi NNP in order to reduce the fragmentation degree and increase the effective mesh size.

Keywords: landscape fragmentation, effective mesh size, protected areas, biodiversity conservation, Western Ukraine.

The fragmentation of natural landscape is a global problem: on one hand, the development of infrastructure contributes to civilization progress, and on the other hand, the increasing degree of anthropogenic fragmentation undermines the stability and reduces the productivity of ecosystems destroying the basis for existing and further progress of the civilization. This line of scientific research is more and more actual all over the world. The importance of landscape fragmentation research rises in those parts of the world where the civilization progress is the most noticeable (Europe, North America, Japan etc.) [1, 3, 4]. In Ukraine the attention to the problem is payed as well [6-9].

Using the appropriate theoretical approaches on the problem we aimed the practical realization of idea on the evaluation of the degree of landscape fragmentation and its effective mesh size $\left(m_{\text {eff }}\right)$ as the index of landscape fragmentation $[2,5]$. Natureprotected areas of the Western Ukraine were chosen to be the subject of our survey.

ISSN 1996-4536 (print) • ISSN 2311-0783 (on-line) • Біологічні Студії / Studia Biologica • 2015 • Том 9/№2 • С. 207-210 
Railways, hard surface roads and completely built-up areas were the factors considered to cause landscape fragmentation. The fragmentation degree of the investigated territories was evaluated by the method of effective mesh size [2].

Seventeen nature-protected areas of eight provinces of Western Ukraine were analyzed in total. On the basis of our survey we found out that total size of a protected area is not the main criterion of its effectiveness in biodiversity conservation. In support of this can witness the pair comparison of areas of National Nature Park Hutsulshchyna and Gorgany Nature Reserve or Carpathian NNP and NNP Skolivski Beskydy where the effective mesh sizes are smaller while total areas are bigger for the first protected sites and vice versa for the last ones (Table).

\section{Fragmentation degree and effective mesh size of nature-protected areas of the Western Ukraine}

Ступінь фрагментації та ефективна площа природоохоронних територій Західної України

\begin{tabular}{|c|c|c|c|c|c|}
\hline Protected sites & $\begin{array}{c}\text { Total area, } \\
\text { sq.km }\end{array}$ & $\begin{array}{c}\text { Number } \\
\text { of clusters* }\end{array}$ & $\begin{array}{c}\text { Number } \\
\text { of fragments** }\end{array}$ & $\begin{array}{c}\mathrm{m}_{\text {eff, }} \\
\text { sq.km }\end{array}$ & $\begin{array}{c}\mathrm{m}_{\text {eff }} \\
\%\end{array}$ \\
\hline Shatskyi NNP & 489.7 & 4 & 9 & 116.5 & 23.8 \\
\hline Cheremskyi NR & 29.8 & 1 & 1 & 27.6 & 92.6 \\
\hline NNP Prypiat-Stokhid & 393.2 & 1 & 4 & 132.5 & 33.7 \\
\hline Rivnenskyi NR & 422.9 & 4 & 4 & 107.7 & 25.5 \\
\hline Yavorivskyi NNP & 71.1 & 1 & 1 & 70.5 & 99.2 \\
\hline Roztochchia NR & 20.9 & 2 & 2 & 8.2 & 39.2 \\
\hline NNP Skolivski Beskydy & 352.6 & 3 & 6 & 219.2 & 62.2 \\
\hline Nadsianskyi RLP & 194.3 & 1 & 4 & 64.6 & 33.2 \\
\hline Uzhanskyi NNP & 391.6 & 1 & 5 & 152.4 & 38.9 \\
\hline NNP Synevyr & 427 & 1 & 3 & 278.4 & 65.2 \\
\hline Carpathian BR & 536.3 & 7 & 9 & 120.8 & 22.5 \\
\hline Carpathian NNP & 515.7 & 1 & 5 & 180.3 & 35 \\
\hline NNP Hutsulshchyna & 322.7 & 1 & 8 & 45 & 13.9 \\
\hline Gorgany NR & 53.4 & 1 & 1 & 53.2 & 99.6 \\
\hline Vyzhnytskyi NNP & 112.4 & 2 & 3 & 73.1 & 65 \\
\hline NNP Dnister Canyon & 108.3 & 1 & 6 & 25.1 & 23.2 \\
\hline Podilski Tovtry NNP & 2613.2 & 1 & 19 & 261.6 & 10 \\
\hline
\end{tabular}

Comments: *Cluster is a part of certain nature-protected area isolated from the rest by territories without a protection regime. ${ }^{* *}$ Fragment is a part of certain nature-protected area separated from the neighboring ones by the fragmentation factors.

Примітки: Кластер - частина певної природоохоронної території, яка ізольована від решти ділянками без заповідного режиму. *^Фрагмент - частина певної природоохоронної території, яка відділена від сусідніх чинниками фрагментації.

We can assert also that a significant degree of landscape fragmentation has a significant negative impact on the index of landscape fragmentation. At the same time the effective mesh size of not-fragmented sites is almost equal to their total area, what undoubtedly ensures the high level of nature protection and biodiversity conservation on their territories. For example, in spite of smaller total area and higher degree of fragmentation in NNP Skolivski Beskydy (352.6 sq.km, 3 clusters, 6 fragments) its effective mesh size and ratio to the total area is bigger than in Carpathian NNP (515.7 sq.km, 1 cluster, 5 fragments) due to the pattern of fragmentation (219.2 sq. km, $62.2 \%$ and 180.3 sq.km,

ISSN 1996-4536 (print) • ISSN 2311-0783 (on-line) • Біологічні Студії / Studia Biologica • 2015 • Том 9/№2 • С. 207-210 
$35 \%$, accordingly). In other words, the area of the largest fragment of NNP Skolivski Beskydy exceeds all the others four times, while the largest fragment of Carpathian NNP is equal to the others. Hence, not only the degree, but also the pattern of fragmentation has a significant influence on the effective mesh size and its percentage expression.

Taking into account the negative effects of landscape fragmentation as one of the threats to biodiversity on the territory of protected sites, we suggest considering the possibility to combine some adjacent protected areas in order to reduce the fragmentation degree and increase the effective mesh size. This should contribute to biodiversity conservation and higher stability of ecosystems as well. The creation of such trans-boundary biosphere reserves as "Eastern Carpathians" or "Western Polissya" are good examples of such approach. In this context we suggest considering the possibility to combine the areas of Roztochchia NR and Yavorivskyi NNP. The idea consists in spatial and administrative integration of these adjacent protected areas. The realization of this will extend the formal protected area $(20.9+71.1=92 \mathrm{sq} . \mathrm{km})$ for one thing. The next thing is that it will reduce the fragmentation degree: Roztochchia NR has 2 clusters and 2 fragments, Yavorivskyi NNP has 1 and 1, integrated area -1 and 1 . And the last important thing, the effective mesh size of integrated area will increase: $8.2 \mathrm{sq} . \mathrm{km}$ for Roztochchia NR, 70.5 sq.km for Yavorivskyi NNP, and 86.1 sq.km for the integrated area. Thus, we expect for a positive environmental effect in general of proposed approach.

1. Bogaert J., Farina A., Ceulemans R. Entropy increase of fragmented habitats: A sign of human impact? Ecological Indicators, 2005; 5: 207-212.

2. Jaeger J.A.G. Landscape division, splitting index, and effective mesh size: new measures of landscape fragmentation. Landscape Ecology, 2000; 15(2): 115-130.

3. Landscape fragmentation in Europe / Joint EEA-FOEN report, 2011. 87 p.

4. Matsushita B., Xu M., Fukushima T. Characterizing the changes in landscape structure in the Lake Kasumigaura Basin, Japan using a high-quality GIS dataset. Landscape and Urban Planning, 2006; 78(3): 241-250.

5. Reshetylo O. Fragmentation of animal habitats: consequences and approaches to its evaluation. In: Condition and biodiversity of ecosystems of Shatskyi National Nature Park. Lviv: Spolom, 2014: 67-68. (In Ukrainian).

6. Reshetylo O.S., Mykitchak T.I. Road mortality of amphibians in Lviv region: problem status and estimating criteria. Vestnik Zoologii, 2008; 42(4): 315-323. (In Ukrainian).

7. Tsaryk J. Urbanization as a factor for insularization of plant populations. In: Urbanization as a factor for changes in biogeocoenotic cover. Lviv: Academic Express, 1994: 12-13. (In Ukrainian).

8. Tsaryk J. Insularization of plant populations and some of its consequences. Scientific Visnyk of State University of Forestry, 1999; 9(9): 202-206. (In Ukrainian).

9. Zagorodniuk I. Animals road mortality: the evaluation of vehicle impact on populations of wild and domestic animals. Fauna in Anthropogenic Environment, 2006; 8: 120-125. (In Ukrainian).

\section{СТУПІНЬ ФРАГМЕНТАЦІї ТА ЕФЕКТИВНА ПЛОЩА ПРИРОДООХОРОННИХ ТЕРИТОРІЙ ЗАХІДНОЇ УКРАЇНИ}

O. Решетило

Львівський національний університет імені Івана Франка вул. Грушевського, 4, Львів 79005, Україна e-mail: reshetylo@yahoo.com

Антропогенна фррагментація природного ландшафту набуває глобального характеру. Зростання ступеня антропогенної фррагментації у світі підриває стійкість 
і знижує продуктивність екосистем. Для втілення ідеї щодо оцінки ступеня фрагментації ландшафту і його ефективної площі використали показник стану фрагментованості ландшафрту $\left(\mathrm{m}_{\mathrm{eff}}\right)$ на прикладі 17 природоохоронних територій Західної України. Чинниками фррагментації вважали залізничні шляхи, автомобільні дороги з твердим покриттям і місця суцільної забудови. На підставі досліджень встановили, що величина загальної площі заповідної території не є головним критерієм її ефрективності у збереженні біорізноманіття, а високий ступінь фрагментації ландшафту має значний негативний вплив на показник ефективної площі. Окрім цього, не лише ступінь, а й характер фррагментації має вагомий вплив на розмір ефективної площі. Беручи до уваги негативні наслідки фррагментації ландшафту як одного з факторів загроз для біорізноманіття на території заповідних об'єктів, пропонуємо розглянути можливість об'єднання суміжних територій ПЗ Розточчя і Яворівського НПП, щоб завдяки цьому знизити ступінь фррагментації та збільшити ефективну площу. Це, на нашу думку, має дати позитивний природоохоронний ефект.

Ключові слова: фррагментаціяландшафту, ефективнаплоща, природоохоронні території, збереження біорізноманіття, Західна Україна.

\section{СТЕПЕНЬ ФРАГМЕНТАЦИИ И ЭФФЕКТИВНАЯ ПЛОЩАДЬ ПРИРОДООХРАННЫХ ТЕРРИТОРИЙ ЗАПАДНОЙ УКРАИНЫ}

\section{О. Решетило}

Львовский национальный университет имени Ивана Франко ул. Грушевского, 4, Львов 79005, Украина e-mail: reshetylo@yahoo.com

Антропогенная фрагментация природного ландшафта приобретает глобальный характер. Увеличение степени антропогенной фрагментации в мире подрывает устойчивость и снижает продуктивность экосистем. Для воплощения идеи относительно оценки степени фрагментации ландшафта и его эффрективной площади использовали показатель состояния фррагментированности ландшафта $\left(\mathrm{m}_{\mathrm{eff}}\right)$ на примеpe 17 природоохранных территорий Западной Украины. Факторами фрагментации считались железнодорожные пути, автомобильные дороги с твердым покрытием и места сплошной застройки. На основании исследований установили, что размер общей площади заповедной территории не является главным критерием ее эффективности в сохранении биоразнообразия, а высокая степень фрагментации ландшафта имеет значительное негативное влияние на показатель эффективной площади. Кроме того, не только степень, но и характер фрагментации имеет значительное влияние на размер эффективной площади. Принимая во внимание негативные последствия фррагментации ландшафта как одного из фракторов угроз для биоразнообразия на территории заповедных объектов, предлагаем рассмотреть возможность объединения смежных территорий ПЗ Расточье и Яворовского НПП, чтобы благодаря этому снизить степень фрагментации и увеличить эффективную площадь. Это, по нашему мнению, должно дать положительный природоохранный эффект.

Ключевые слова: фррагментация ландшафта, эффеективная площадь, природоохранные территории, сохранение биоразнообразия, Западная Украина.

Одержано: 01.09.2015

ISSN 1996-4536 (print) • ISSN 2311-0783 (on-line) • Біологічні Студії / Studia Biologica • 2015 • Том 9/№2 • С. $207-210$ 